\title{
Planning Green Infrastructure as a Source of Urban and Regional Resilience - Towards Institutional Challenges
}

\author{
Paulina Schiappacasse \\ Bernhard Müller
}

Paulina Schiappacasse, Technische Universität Dresden, Germany (paulina.schiappacasse@tu-dresden.de) Bernhard Müller, Leibniz Institute of Ecological Urban and Regional Development (IOER), Germany (B.Mueller@ioer.de)

\begin{abstract}
Green infrastructure programmes and strategies are regarded as planning opportunities to promote sustainable and resilient urban development. However, the discourse about green infrastructure policy and its effectiveness has pointed to the limited success in practical implementation. Since the green infrastructure has no planning status in its own right, it depends on being embedded in comprehensive urban and regional planning approaches if it is to have an impact on sustainable and resilient urban development. At the same time spatial planning may contribute to providing a platform for its institutionalisation.

Against this backdrop, the article first looks at the contents of urban resilience. Secondly, we discuss principles for planning resilient cities. Thirdly, we analyse how green infrastructure initiatives can foster these principles contributing to building urban and regional resilience. Fourthly, we discuss the challenges facing the institutionalisation of green infrastructure initiatives. Finally, we draw conclusions about the future role of spatial planning in the process of institutionalising green infrastructure strategies.
\end{abstract}

Keywords: green infrastructure, urban resilience, spatial planning, institutional challenges

\section{Introduction}

The world population is increasingly urban and most future growth is expected to take place in small and medium cities (United Nations, 2014). Moreover, "if current trends in population density continue and all areas with probabilities of urban expansion undergo change", around $60 \%$ of the projected total urban area in 2030 has yet to be built (Seto et al., 2012:16083; Secretariat of the Convention on Biological Diversity, 2012). In Europe, "while most urban areas are now slow growing (at $0.5-0.7 \%$ per year), built development in periurban areas is growing at four times this rate" (Nilsson in Piorr, Ravetz and Tosics, 2010:10). Although urbanisation rates in Europe have been small and constant since the 1970's, current and future environmental and demographic challenges have resulted in growing interest in the ways green spaces can benefit cities and inhabitants. Thus, planning for green infrastructure has become a common topic of discussion for promoting sustainable and resilient urban areas.

Urban resilience is about the ability of the city region, i.e. its institutions and population, and its action to prepare for, react to, and recover from sudden shocks and long term disruptions (Table 1), and to maintain its central functions (i.e. critical infrastructure) when exposed to these events. Of significance here is the development of flexible, adaptive and resistant (social, physical and institutional) city and regional structures that can both reactively and proactively adapt to changing framework conditions. Planning strategies oriented towards resilience can support sustainable urbanisation patterns by promoting riskinformed decisions tested against multiple uncertainties (United Nations, 2015). As such, building urban and regional resilience is a constant planning process that extends beyond disaster preparedness and contingency planning.

Scientific contributions to the understanding of the concept of urban resilience, its operationalisation (i.e. finding answers to: resilience of what, to what and for whom), and its 
contribution to policy development have increased considerably in environmental sciences (Schiappacasse and Müller, 2015). However, the discussion surrounding the drivers enabling a city region to prepare and recover from stresses have received less attention. Fortunately, the institutional grey literature has made substantial contributions to the subject, specifically on promoting resilience design guidelines (DESURBS Project, 2014; Interagency Resilience Working Group, 2012), on identifying technical tools for quantifying and assessing impacts (United Nation Environmental Programme, 2014; Abhas et al.,2013), and in discussing successful practices regarding disaster management (The Rockefeller Foundation, 2015a, 2015b; The World Bank, 2013; USAID, 2012; International Federation of Red Cross and Red Crescent Societies, 2009).

Table 1: Classification of sudden shocks and long term disruption (resilience to what).

\begin{tabular}{|c|c|c|}
\hline Natural/Biological & Technological & Socio-economic and political \\
\hline $\begin{array}{ll}\text { Epidemic } & \text { and } \\
\text { pandemic } & \end{array}$ & Chemical spill & Housing crisis \\
\hline Drought & Explosion & Energy crisis \\
\hline Extreme temperature & Fire & Food and water crisis \\
\hline Wildfire & Oil spill & Demographic change \\
\hline Earthquake & Poisoning & Economic crisis \\
\hline Mass movement & Radiation & Terrorism \\
\hline Volcano & $\begin{array}{l}\text { Critical infrastructure } \\
\text { breakdown }\end{array}$ & Social conflict \\
\hline Flood & & War \\
\hline Storm & & Political conflict \\
\hline
\end{tabular}

Source: Adapted from United Nations (2015)

\section{Objectives and Method \\ Objectives}

Although the driving forces for fostering resilience depend on the specific case (resilience of what and to what), we believe that a number of planning elements regarding design, implementation and management are generalizable in order to enhance resilience at different spatial scales. In this context, the objective of this article is twofold: first, to improve our understanding of the principles of urban resilience from a spatial planning perspective, and second, to analyse the strengths and weaknesses for institutionalising green infrastructure practice as an effective approach for building urban resilience.

\section{Method: Principles for planning resilient city regions}

Biggs, Schlüter and Schoon (2015) have identified seven principles for fostering resilience. On this basis, we will discuss in the following how spatial planning can enhance the resilience of the city region. The planning principles to enhance the urban resilience are:

Promote diversity: Promoting and sustaining diversity in all forms, e.g. related to biological, land use, social and economic issues, and encouraging multiple resources to balance current homogenising trends, is essential for building resilience (Walker and Salt, 2006). Diversity also means to embrace a range of management strategies (scenarios) to face uncertainties.

Manage connectivity: Spatial connectivity is important to understand the relationship between inhabitants, species and their surrounding landscapes (Auffret et al., 2015). Spatial biotic (organisms) and abiotic (water, electricity) connectivity have both structural and functional dimensions in urban systems. Structural connectivity describes the physical relationship or distance between areas (i.e. neighbourhoods, squares, landscapes, and patches 
of ecological habitat) while functional connectivity is the degree to which these areas facilitate or impede the movement of organisms and processes of ecosystems. Structural connectivity is often used as a proxy for functional connectivity, although the movements of people and species are not necessarily correlated with the physical connections among areas. Connectivity can have positive or adverse effects on building resilience. For instance, local failures in highly connected systems might lead to a systemic collapse (e.g. disease spread, water quality).

Manage control variables: Control variables are those that govern the role and impacts of inhabitants within the city region, and can be planned or modified to achieve certain objectives, like building resilience. Thus, land use zoning, strategic master plans, norms and legal systems are control variables that can influence the preparation for and reaction to uncertainties (Herrfahrdt-Pähle and Pahl-Wostl, 2012). With regard to choosing the level of control of the variable (e.g. incentives, penalties and compensation measures), each strategy will produce different patterns of spatial interaction.

Foster urban complex system thinking: The city region is a complex system of interrelated stakeholders where multiple interactions occur at the same time on different spatial levels. System thinking helps to anticipate rather than react to events, and better prepare for emerging disruptions. In practice, system thinking means to build and obtain knowledge, to accept and prepare for uncertainties and change (Table 1), and to recognize diverse development perspectives or trajectories (e.g. transformation, adaptation).

Encourage learning practices and knowledge-building: Because city regions are in constant change, it is necessary regularly to revise existing knowledge about disruptions and management strategies to enable adaptation to change and to prepare for transformation. Building up knowledge involves learning from other experiences, adding to codified knowledge and proposing future actions (Miranda and Bau, 2014). Sharing learning approaches helps to establish or strengthen networking among different stakeholders at different spatial scales. However, this may face considerable challenges - political, institutional, environmental - in which the nature and value of building urban resilience is contested (Orleans Reed et al., 2013).

Encourage participation and partnership: Incorporating all stakeholders in decision making improves legitimacy, expands the depth and diversity of knowledge and helps to detect and interpret change and disruptions. Resilience grows as the network of stakeholders strengthens linkages in the system. These linkages promote dialogue and collaboration to address emerging problems or crises.

Deal with multi-level governance: Multi-level governance refers to an organisational structure where multiple, independent actors mutually order their relationships under general systems of rules (Araral and Hartley, 2013). Institutions and organisations have to be connected through a set of strategies, plans and norms that interact across hierarchies and spatial levels. Formal and informal planning instruments can overlap in objectives, providing a diversity of responses of differing strength. Additionally, urban regions often comprise a multiple administrative subdivision which might complicate the management of ecological, social and economic dynamics in terms of avoiding mismatches (Puckett et al., 2001 in Bergsten et al., 2014). Not infrequently, management organisations do not match with the spatial scales they deal with (Garmenstani and Harm Benson, 2013).

\section{Results}

\section{Green Infrastructure as a planning action for building urban resilience}

Like other concepts in vogue in environmental planning (e.g. resilience, sustainability, and inclusiveness), green infrastructure does not have one recognized definition. Numerous definitions of green infrastructure can be found in academic sources (Kambites and Owen, 
2006; Hansen and Pauleit, 2014), though little theoretical development is to be observed since its seminal description by Benedict and Mc Mahon (2002) ${ }^{1}$. Despite the lack of applicationoriented frameworks, political agendas are taking advantage of the concept. For instance, green infrastructure has been defined and promoted by the European Union ${ }^{2}$ as one of the investment priorities contributing to regional policy and sustainable growth in Europe and facilitating smart and sustainable growth through smart specialization (European Union, 2011; European Union, 2012). As Wright (2011) mentions, although the concept of green infrastructure is still evolving and has developed in response to different needs (design, landscape ecology, environment, and socio-economic), there is consensus on three interrelated ideas shaping green infrastructure initiatives: connectivity, multi-functionality, and "green" (representing commonly the elements that play the environmental role for improvement).

In recent years, "green infrastructure planning" (Benedict and McMahon, 2006; Kambites and Owen, 2006; Mell, 2009; Hansen and Pauleit, 2014) has been recognized as a tool for safeguarding sustainable development on the basis of a holistic understanding of combining ecological, social and economic benefits. The literature dealing with green infrastructure planning - as opposed to that on the green infrastructure as such - is not extensive. We highlight the contribution by Ahern (2007), who classifies green infrastructure as an "opportunistic" planning strategy.

In line with the views of Mell (2009) and Hansen and Pauleit (2014), we do not think green infrastructure represents a new approach in spatial planning, though green infrastructure initiatives require the incorporation of specific planning approaches for its successful implementation. In this section, we discuss how, from the spatial planning perspective, the principles for building resilient city-regions can be "theoretically activated" through the implementation of green infrastructure initiatives:

Promote diversity: The main characteristic of green infrastructure initiatives are their multi-functionality which allows several economic, social and ecological benefits in the same spatial area (Table 2). These functions "shall be explicitly considered instead of being a product of chance" (Hansen and Pauleit, 2014: 518). As such, green infrastructure projects can be considered a win-win, integral strategy tackling several challenges within a financially viable framework. Their multi-functionality character makes green infrastructure strategies different from "grey perspectives" which tend to be designed to fulfil one function like drainage (Naumann et al., 2011).

Manage connectivity: The idea that connecting the systems of parks and green ways is more beneficial than isolated green spaces is not new. Introduced in the twentieth century by Frederick Law Olmsted (Eisenmann, 2013), green infrastructure is a planned or unplanned network, spanning both the public and private realms, and managed as an integrated system to provide a range of benefits (Norton et al., 2015). Spatial connectivity refers to the design, planning and management of the green infrastructure system as a whole to ensure the integrity of the network. As such, green infrastructure is not only about connecting ecosystems per se; it is also about strengthening them and their services, re-connecting built-up urban areas and improving landscape permeability (European Environment Agency, 2011). There is a growing literature on methods to identify, articulate and assess the spatial dimension of multifunctional components of green infrastructure (European Environment Agency, 2014; Ahern, 2007).

\footnotetext{
1 “... an interconnected network of green space that conserves natural ecosystem values and functions and provides associated benefits to human populations“(Benedict and McMahon, 2002: 5).

2 “... a strategically planned network of natural and semi-natural areas with other environmental features designed and managed to deliver a wide range of ecosystem services. It incorporates green spaces (or blue if aquatic ecosystems are concerned) and other physical features in terrestrial (including coastal) and marine areas. On land GI is presented in rural and urban settings" (EU 2013).
} 
Manage control variables: Green infrastructure projects can be a management tool serving different needs and in different contexts. For instance, following Wright (2011), green infrastructure in the U.S. has become a resource for smart conservation and protection while in the U.K it is more concerned with controlling urban development (e.g. Green Belt policy). In Germany, recreation and urban control functions have been extended in practice to climate change adaptation initiatives. Standardizing and regulating green infrastructure initiatives involves more than writing new regulations (e.g. on zoning, subdivision and environmental standards). The system of granting planning permission needs to be reconsidered to meet new criteria such as connectivity and multi-functionality. It is necessary to review existing laws, policies and practices affecting land-use decisions. Green infrastructure initiatives can also help maximize benefits and manage conflicting land use demands and pressures, like those of housing, industry, transport, energy, agriculture, nature conservation, recreation and aesthetics. However, with several stakeholders involved, a conflict of interests is highly probable. Some potential conflicts (Table 3) can be avoided through appropriate mediation instruments or collaborative implementation practices.

Table 2: Functions and benefits of Green Infrastructure.

\begin{tabular}{l} 
Function \\
\hline Aesthetic \\
Land and property values \\
Social-psychological \\
Education and culture \\
$\begin{array}{l}\text { Recreational, well-being and } \\
\text { health }\end{array}$
\end{tabular}

\section{Biodiversity/species protection and conservation benefits}

Climate and climate change

\section{Water management}

Food production and security

\section{Benefits}

Makes an area characteristic

Links places of living and activities; positive impact on land and properties

Attractive living environment; social inclusion; sense of community

Understanding and experiencing nature; opportunities for education and training; connectivity between urban and rural areas

Nature close to housing; sense of space and nature Tourism/ecotourism; social interaction; improving mental and physical health

Species protection; habitat for species; connecting habitats and guiding species movements

Mitigating urban heat island effect; storing floodwater and ameliorating surface water run-off to reduce flooding risk

Carbon sequestration; reducing energy use for heating and cooling buildings; encouraging sustainable travel

Attenuating surface water run-off; fostering groundwater infiltration

Keeping potential for agriculture land; soil development and nutrient cycling; preventing soil erosion

Source: adapted from Jongman, et al. (2013); European Environment Agency (2011)

Foster urban complex system thinking: The multifunctional character of green infrastructure reflects system thinking (adaptation and transformation). For instance an area suitable for flood protection can serve for recreational purposes, preservation of cultural heritage, natural pasture land for cattle and a habitat for wildlife (European Commission, 2012 in Baró et al., 2015). Furthermore, a green infrastructure strategy might comprise a wide 
range of environmental features operating at different scales (Table 4). As a prominent example, the EU green infrastructure strategy (European Union, 2013) aims at mainstreaming green infrastructure in urban and regional planning in order to take account of the manifold benefits we can obtain from nature. The strategy draws on the EU Resource Efficiency Roadmap and the Biodiversity Strategy to 2020.

Table 3: Potential conflicts arising from particular instruments of EU sector policies and green infrastructure benefits.

\begin{tabular}{ll}
\hline EU Sector Policy Area & Potential conflict description \\
\hline Climate Change & $\begin{array}{l}\text { Carbon sequestration measures can affect biodiversity } \\
\text { Invasive alien species threaten other ecosystem services, spread } \\
\text { of allergens in plants, physical damage to build infrastructure } \\
\text { by decomposition of tree roots } \\
\text { Securing energy supply (gas pipelines, gridlines) can damage } \\
\text { habitat connectivity and decrease areas of GI. Failures and } \\
\text { leakages might affect habitat preservation. } \\
\text { Efforts to minimize congestion can result in the construction of } \\
\text { new roads, damaging habitat connectivity and decreasing areas } \\
\text { of GI }\end{array}$ \\
\hline
\end{tabular}

Source: European Environment Agency (2011)

Table 4: Features of green infrastructure operating at different scales.

\begin{tabular}{lll}
\hline Neighbourhood & City & City-region \\
\hline $\begin{array}{l}\text { Street trees, verges and } \\
\text { hedges }\end{array}$ & Business settings & Regional parks \\
$\begin{array}{l}\text { Green roofs and walls } \\
\text { Private gardens }\end{array}$ & City/district parks & Rivers and floodplains \\
Urban plazas & Urban canals & Shorelines \\
Local rights of way & Urban commons & Long distance trails \\
Pedestrian and cycle routes & Forest and country parks & Forest and woodlands \\
Cemeteries and churchyards & Continuous waterfronts & Reservoirs \\
& Municipal plazas & Road and railway \\
Institutional open spaces & Lakes & Grworks \\
Ponds and streams & Major recreational spaces & Agricultural land \\
Play areas & Rivers and floodplains & National parks \\
School grounds & (Former) & Canals \\
& extraction sites & Common lands \\
Allotments & Agricultural land & Open countryside \\
Vacant and derelict land & Landfill & \\
\hline
\end{tabular}

Source: adapted from European Environment Agency (2011)

Encourage learning practices and knowledge-building: Only recently has systematic guidance been provided for planning practitioners on how green infrastructure can be enhanced and promoted through planning systems (Pauleit et al., 2011; Mazza et al., 2011; Town \& Country Planning Association, 2012; Stockholm University, 2012; Civic and Siuta, 2014). For instance small initiatives or isolated projects can enhance green infrastructure efforts enabling city resilience or leading to transformation at a larger scale (Taylor Lowell and Taylor, 2013). Green infrastructure can promote urban sustainability and resilience by retrofitting interstitial spaces that have little value otherwise into the urban fabric. Vacant lots 
can be used as new markets for fresh food, supporting social interaction and improving health through physical activity.

Encourage participation and partnership: Green infrastructure functions cross scales and jurisdictions; without local and regional involvement and agreement they will thus not succeed. Broad participation and partnership can hence be expected to safeguard the spatial whole. Engaging all actors in green infrastructure planning and design encourages commitment, builds trust, and creates resilient outcomes. On the local and regional levels, green infrastructure approaches have recently broadened, strongly promoting self-governance, i.e. decision making and management structures where self-organising non-state actor groups play a major role, and where state authorities have a more distant, perhaps facilitating or even absent role (Arnouts et al., 2013 in Buizer et al., 2015).

Deal with multi-level governance: In accordance with its inherent multi-functional character, one of the main strengths of green infrastructure strategies is the involvement of several policy areas with responsibilities ranging from the regional to the local level (Naumann et al., 2011). For instance, Baró et al., 2015 mention the European policy sectors suitable for this integration: climate, water and nature conservation (via the EU Biodiversity Strategy to 2020), regional policy, land, and soil. The EU strategy clearly mentions the role of national and regional authorities in guiding, planning and managing green infrastructure.

\section{Challenges to institutionalising green infrastructure initiatives}

Despite its promise as a cost effective and multi-beneficial beneficial strategy, green infrastructure faces open challenges to implementation. In this section we discuss the institutional challenges that seem to be consistent across scales of implementation:

Multifunctional framework: The benefits of multi-functionality are often not addressed, owing perhaps to the traditional individual management perspective. Green infrastructure initiatives have hitherto been more of a 'layering of focuses' deriving from specific agendas and individual actors than a comprehensive approach. For instance, the social role of green infrastructure has been neglected as a catalyst to economic growth (attracting investments, generating employment, contributing to local food production, and increasing real estate values). Green infrastructure needs to be conceived in the same way as other infrastructure, e.g. to be designed and implemented as a whole, rather than as separate, unrelated parts. As Wolf 2004 (in Schäffler and Swilling, 2013) states: "A city would never build a road, water or electrical system piece by piece, with no advanced planning or coordination. Green Infrastructure is that idea that nature in cities should be administered in an integrated way, just as grey infrastructure systems have been."

Mismatch between theory and practice: According to some researchers, the ambiguities of the green infrastructure concept, especially in its relationship with ecosystem services (Wright, 2011; Hansen and Pauleit, 2014), cause confusion and "permit political agendas to take advantage of the concept, hindering practical application" (Collinge, 2010 in Wright, 2011). Green infrastructure is too broad a concept to be practically feasible Wright (2011). Commonly, initiatives labelled green infrastructure rarely relate to the concept (Mazza et al., 2011).

Knowledge transfer: One common criticism of green infrastructure initiatives is the lack of empirical frameworks taking a holistic perspective. Insights from conceptual definitions have not been translated into empirical proposals on how these assets can be taken into account by city planning authorities. Moreover, according to Hansen and Pauleit (2014), numerous European initiatives to establish ecological networks overlap with green infrastructure principles, but rarely relate to the concept. What is more, demonstration projects, like green infrastructure living laboratories, can be considered a creative small-scale practice for testing and monitoring specific goals. 
Lack of formal planning status: Green infrastructure is more a synthesis of different planning approaches - strategic, adaptive, participatory and collaborative planning (Hansen and Pauleit, 2014:517) - than a unique approach. Finally, approaches for the operationalisation of multi-functionality as a planning principle are still missing.

Common management area: The idea of green infrastructure as a common management territory implies actor participation on equal terms. However, in practice different interests are in constant competition, as actors have different objectives and outcomes "labelled the same" (Wright, 2011).

Genuine participation: According to Taylor-Lowell and Taylor (2013: 1457), green infrastructure initiatives are oriented more towards the political and economic interests of urban elites than towards establishing broad and constant participation and incorporating all stakeholders. Green infrastructure projects (e.g., greenways and restored waterfronts) have often been imposed from above and symbolically re-inserted in the city as the discursive construction of the sustainable city.

Financial constrains: Even though research has produced evidence of the benefits provided by green infrastructure, many cities struggle to find the resources and coordination capacity to implement and maintain green infrastructure agendas (Taylor-Lowell and Taylor, 2013). Green infrastructure, like any kind of infrastructure, has long-term maintenance and renewal costs. The evaluation of green infrastructure functions by cost-benefit analysis could help cities to justify investments.

\section{Conclusions}

Green infrastructure is a concept that entered the sustainability and resilience discourses across a wide range of organisations and planners. Initiatives appear to be a good tool for building resilience since, in theory, they address the dynamic interplay of ecological and social urban systems, incorporating common driving forces (connectivity, adaptation, participation and cooperation).

As a new concept (not a new idea), the scope, implications, and implementation of green infrastructure and measures of its effectiveness must be defined and negotiated at all levels. As in other infrastructure systems, the role and function of the entities that regulate, build, operate and maintain green infrastructure must be defined. As in most negotiations, certain principles will prevail over others.

As green infrastructure encompasses different planning principles and approaches, it cannot be considered a holistic planning approach. Spatial planning may provide a platform (through instruments, regulations and agencies) for its institutionalisation. A crucial question for planners is how green infrastructure can be integrated into other policy sectors like social cohesion, water, energy, agriculture or transport.

Green infrastructure strategies constitute an opportunity to be "grasped in practice and sustained" for sustainable and resilient cities (Kambites and Owen 2006). Although its implementation still faces many challenges, planners need to concentrate their efforts on developing a compelling vision of the concept, on initiating extensive outreach and on promoting interdisciplinary and inter-sectoral cooperation.

\section{References}

Abhas, K. J., Miner, T. W. \& Stanton-Geddes, Z. (2013) Building Urban Resilience. Principles, Tools, and Practice. Washington D.C., The World Bank. Available at: https://www.gfdrr.org/sites/gfdrr/files/publication/Building_Urban_Resilience.pdf (accessed Dec.6) 
Ahern, J. (2007) Green Infrastructure for Cities: The Spatial Dimension. In: Novotny, V. \& Brown, P. (eds.) Cities of the future: Towards Integrated Sustainable Water and Landscape Management. London, IWA Publishing.

Araral, E. \& Hartley, K. (2013) Polycentric Governance for a New Environmental Regime: Theoretical Frontiers in Policy Reform and Public Administration. Typescript.

Buizer, M., Elands, B., Mattijssen, T., Van der Jagt, A., Ambrose B., Gerohazi E., Santos, A., Steen Moller, M. (2015) The Governance of Urban Green Spaces in Selected EU-Cities. Policies, Practices. Actors, Topics. EU FP7 project Green Surge. Available at: http://greensurge.eu/workingpackages/wp6/files/Buizer_et_al_2015_D6.1_GREEN_SURGE_The_governance_of_urb an_green_spaces_in_selected_EU_cities.pdf (accessed: 6 Dec. 2015).

Auffret, A.G., J. Plue., S.A.O. Cousins. 2015. The spatial connectivity and temporal components of functional connectivity in fragmented landscapes. Ambio, 44 (1), pp. 5159. DOI: 10.1007/s 13280-014-0588-6

Baró, F., Bugter, R., Gómez-Baggethun, E, Hauck, J., Kopperoinen, L., Liquete, C., Potschin, P. (2015) Green Infrastructure. In: Potschin, M. \& Jax, K. (eds.) OpenNESS Ecosystem Service Reference Book. EC FP7 Grant Agreement no. 308428. Available at: http://www.openness-project.eu/library/reference-book/ (accessed: 6 Dec.2015).

Benedict, M.A., \& McMahon, E.T. (2002) Green infrastructure: Smart conservation for the $21^{\text {st }}$ century. Sprawl Watch Clearinghouse Monograph Series. Available at: www.sactree.org/assets/files/greenprint/toolkit/b/greenInfrastructure.pdf (accessed: 6 Dec. 2015).

Bergsten, A., Galafassi, D., Bodin, O. (2014) The problem of spatial fit in social-ecological systems: detecting mismatches between ecological connectivity and land management in an urban region. Ecology and Society, 19(4):6. DOI: 10.5751/ES-06931-190406

Biggs, R., Schlüter, M. \& Schoon, M.L. (eds.) (2015) Principles for Building Resilience. Sustaining Ecosystem Services in Social-Ecological Systems. Cambridge, Cambridge University Press.

Civic, K. \& Siuta, M. (2014) Green Infrastructure-Training manual for trainers. ECNC, Tilburg, the Netherlands and CEEweb for Biodiversity, Budapest, Hungary. Available at: http://www.ceeweb.org/wp-content/uploads/2014/06/GI-training-materials-CEEweb-andECNC1.pdf (accessed: 6 Dec. 2015).

DESURBS. 2014. Urban Resilient Design Guidelines. Designing Safer Urban Spaces Project. Desurbs, EU,7FP, Bezalel. Available at: http://researchmgt.com/DESURBS/final/wpcontent/uploads/2015/03/URDG_file.pdf (accessed: 6 Dec.2015).

Eisenmann, T.S. (2013) Frederick Law Olmsted, Green Infrastructure, and the Evolving City. Journal of Planning History, 0 (0), pp. 1-25. DOI: 10.1177/1538513212474227

European Commission (2012) The multi-functionality of Green Infrastructure. Science for Environment Policy. In In-depth Reports. Available at:

http://ec.europa.eu/environment/nature/ecosystems/docs/Green_Infrastructure.pdf (accessed: 6 Dec.2015).

European Environment Agency (2014) Spatial analysis of green infrastructure in Europe. EEA Technical report No. 2/2014. Luxembourg, Publication Office of the European Union.

European Environment Agency (2011) Green Infrastructure and territorial cohesion. The concept of green infrastructure and its integration into policies using monitoring systems. EEA Technical Report No. 18/2011. Luxembourg, Publication Office of the European Union.

European Union (2013) Green Infrastructure (GI) - Enhancing's Europe's Natural Capital. Communication from the Commission to the European Parliament, the Council, the 
European Economic and Social Committee and the Committee of the Regions. European Commission. Available at: http://eur-lex.europa.eu/resource.html?uri=cellar:d41348f201d5-4abe-b817-4c73e6f1b2df.0014.03/DOC_1\&format=PDF (accessed: 6 Dec.2015).

European Union (2012) Connecting smart and sustainable growth through smart specialization. A practical guide for ERDF managing authorities. Available at: http://ec.europa.eu/regional_policy/sources/docgener/presenta/green_growth/greengrowth. pdf (accessed: 6 Dec.2015).

European Union (2011) Regional Policy contributing to sustainable growth in Europe 2020. Commission Staff Working Document, Available at: http://ec.europa.eu/regional_policy/sources/docoffic/official/communic/sustainable/swd_s ec2011_92.pdf (accessed: 6 Dec.2015).

Garmenstani, A.S., \&. Harm Benson, M. (2013) A framework for Resilience-based Governance of Social-Ecological Systems. Ecology and Society, 18 (1). DOI: 10.5751/ES05180-180109.

Hansen, R., \& Paulei, S. (2014) From multifunctionality to Multiple Ecosystem Services? A Conceptual Framework for Multifunctionality in Green Infrastructure Planning for Urban areas. Ambio, 43, pp. 516-529. DOI: 10.1007/s13280-014-0510-2

Herrfahrdt-Pähle, E., \& C. Pahl-Wostl, C. (2012) Continuity and change in social-ecological systems: the role of institutional resilience. Ecology and Society, 17 (2):8.DOI: 10.5751/ES-04565-170208

Interagency Resilience Working Group (2012) The Characteristics of Resilience Building. A discussion paper. Available at: http://technicalconsortium.org/wpcontent/uploads/2014/05/The-Characteristics-of-Res_Building.pdf (accessed: 6 Dic.2015)

International Federation of Red Cross and Red Crescent Societies (2009) Disaster reduction programme 2001-2008. Summary of lessons learned and recommendations. Available at: http://www.ifrc.org/Global/Publications/disasters/dr-programme-en.pdf (accessed 6 Dec. 2015)

Jongman, R., Steingröver, E., Bouwma, I. \& Vos, C. (2013) Spatial planning of Green Infrastructure in a changing climate. Proceedings of the European Conference on Climate change and Nature Conservation in Europe - an ecological, policy and economic perspective. Available at: https://www.bfn.de/fileadmin/MDB/documents/service/Skript_367.pdf (accessed 6 Dec. 2015)

Kambites, C., \& Owen, S. (2006) Renewed Prospects for Green Infrastructure Planning in the UK. Planning. Practice \& Research, 21 (4), pp. 483-496. DOI: 10.1080/02697450601173413

Mazza. L., Bennett. G., De Nocker. L., Gantioler. S., Losarcos. L., Margerison. C., Kaphengst. T., McConville. A., Rayment. M., Ten Brink, P., Tucker G., van Diggelen, R. (2011) Green Infrastructure Implementation and Efficiency. Final report for the European Commission. Brussels and London, Institute for European Environmental Policy.

Miranda, L. \& Bau, I. (2014) Knowledge-building in adaptation management: concertación processes in transforming Lima water and climate change governance. Environment \& Urbanization, 26 (2), pp. 505-524.

Mell, I.C. (2009) Can Green Infrastructure promote urban sustainability? Proceedings of the ICE - Engineering Sustainability, 162 (ES1), pp. 23-24. DOI: 10.1680/ensu.2009.162.1.23

Naumann S., McKenna, D. \& Kaphewngdst, T. (2011) Design, implementation and cost elements of Green Infrastructure projects. Final report. Brussels, European Commission. 
Norton, B.A., Coutts, A.M., Livesley, S.J., Harris, R.J., Hunter, A.M., Williams, N.S.G.. (2015) Planning for cooler cities: A framework to prioritize green infrastructure to mitigate high temperatures in urban landscapes. Landscape and Urban Planning, 134, pp.127-138. DOI: 10.1016/j.landurbplan.2014.10.018

Orleans Reed, S., Friend, R., Canh Toan, V., Thinphanga, P., Sutarto, R. \& Singht, D. (2013) "Shared learning" for building urban climate resilience - experiences from Asian cities. Environment and Urbanization, 25 (2), pp. 393-412. DOI: 10.1177/0956247813501136

Pauleit, S., Liu, L., Ahern, J. \& Kazmierczak, A (2011) Multifunctional green infrastructure planning to promote ecological services in the city. In: Niemelä, J. (eds.) Urban Ecology. Patterns, processes, and applications, pp. 272-285. New York, Oxford University Press Inc..

Piorr, A., Ravetz J., Tosics, I. (eds.) (2010) Peri-Urbanization in Europe. Towards European Policies to Sustain Urban-Rural Futures. Synthesis Report. Available at: http://www.openspace.eca.ed.ac.uk/pdf/appendixf/Peri_Urbanisation_in_Europe_printver sion.pdf (accessed 6 Dec.2015)

Schäffler, A. \& Swilling, M. (2013) Valuing green infrastructure in an urban environment under pressure. The Johannesburg case. Ecological Economics, 86, pp. 246-257. DOI: 10.1016/j.ecolecon.2012.05.008

Schiappacasse, P., \& Müller, B. (2015) One fits all? Resilience as a multipurpose concept in regional and environmental studies (submitted)

Secretariat of the Convention on Biological Diversity (2012) Cities and Biodiversity Outlook. Montreal, Secretariat of the Convention on Biological Diversity.

Seto, K.C., Güneralp, B. \& Hutyra, L.R. (2012) Global forecasts of urban expansion to 2030 and direct impacts on biodiversity and carbon pools". Proceedings of the National Academy Sciences of the United States of America, 109 (40), pp. 16083-16088. DOI: 10.1073/pnas. 1211658109

Stockholm University (2012) Cities and Biodiversity Outlook, Action and Policy. A Global Assesment of the Links between Urbanization, Biodiversity, and Ecosystem Services. Available at: https://www.cbd.int/doc/health/cbo-action-policy-en.pdf (accessed Dec.6)

Taylor Lowell, S. \& Taylor, J. R. (2013) Supplying urban ecosystem services through multifunctional green infrastructure in the United States. Landscape Ecology, 28, pp. 1447-1463. DOI: 10.1007/s10980-013-9912-y

The Rockefeller Foundation (2015a) City Resilience and the City Resilience Framework. 100 Resilient Cities. Available at: http://www.100resilientcities.org/page//100rc/What\%20is\%20City\%20Resilience\%20\%26\%20the\%20CRF\%20\%20100\%20Resilient\%20Cities_4.pdf (accessed Dec.6)

The Rockefeller Foundation (2015b) Ten Cities, Four Countries, Five Years: Lessons on the Process of Building Urban Climate Change Resilience. Available at: https://www.rockefellerfoundation.org/report/ten-cities-four-countries-five-years-lessonson-the-process-of-building-urban-climate-change-resilience/ (accessed Dec.6)

Town \& Country Planning Association and The Wildlife Trusts (2012) Planning for Healthy environment - Good Practice Guidance for Green Infrastructure and diversity. Available at: http://www.tcpa.org.uk/data/files/TCPA_TWT_GI-Biodiversity-Guide.pdf (accessed Dec.6)

United Nations (2015) Habitat III Issue Papers and Policy Units of the Habitat III Conference. Available at: http://unhabitat.org/wp-content/uploads/2015/04/Habitat-III-Issue-Papersand-Policy-Units_11-April.pdf (accessed Dec.6)

United Nations, Department of Economic and Social Affairs, Population Division (2014) World Urbanization Prospects: The 2014 Revision, Highlights (ST/ESA/SER.A/352). 
Available at: World Urbanization Prospects: The 2014 Revision, Highlights (accessed Dec.6)

USAID (2012). Building Resilience to Recurrent Crisis. USAID Policy and Program Guidance. Available at:

https://www.usaid.gov/sites/default/files/documents/1870/USAIDResiliencePolicyGuidan ceDocument.pdf (accessed Dec.2014)

Walker, B., \& Salt, D. (2006) Resilience thinking. Washington, Island Press.

Wright, H. (2011) Understanding green infrastructure: the development of a contested in

England. Local environment. The International Journal of Justice and Sustainability, 16, pp. 1003-1019. DOI: 10.1080/13549839.2011.631993 